\title{
KARAKTERISTIK PEMBAKARAN DAN KARAKTERISTIK MEKANIS KOKAS IMPOR SEBAGAI BAHAN BAKAR DAPUR KUPOLA
}

\author{
Sartono Putro \\ Jurusan Teknik Mesin Fakultas Teknik Universitas Muhammadiyah Surakarta \\ Jl.A. Yani Kotak Pos 1 Pabelan Kartasura \\ sartono putro@ums.ac.id
}

\begin{abstract}
ABSTRAK
Kokas merupakan bahan bakar utama dalam industri pengecoran logam. Kokas yang digunakan kebanyakan diimpor dari Cina sehingga sangat rentan terhadap fluktuasi harga. Penelitian ini bertujuan untuk mengetahui karakteristik mekanis dan karakteristik pembakaran kokas impor, sebagai pembanding juga dilakukan penelitian kokas lokal (green coke). Penelitian diawali dengan membentuk bongkahan-bongkahan kokas impor dan green coke menjadi silinder berdiameter $4 \mathrm{~cm}$ panjang $8 \mathrm{~cm}$ untuk pengujian sifat mekanik, dan silinder dengan diameter 2,3 cm massa 5 gram untuk pengujian pembakaran. Selanjutnya dilakukan pengujian kandungan bahan dasar, kekuatan mekanik meliputi uji tekan dan uji kejut dan karakteristik pembakaran meliputi laju pembakaran, pengurangan masa, dan temperatur pembakaran. Hasil penelitian menunjukkan bahwa kuat tekan kokas impor 3,9 kali kuat tekan green coke yaitu $168,939 \mathrm{~kg} / \mathrm{cm}^{2 P}$ dibanding 43,182 kg/cmP $P^{2 P}$, sedangkan kuat kejut kokas impor 3,6 kali green coke. Adapun pada uji laju pembakaran tertinggi terjadi pada temperatur puncak pembakaran kedua kokas. Laju pembakaran terbesar dimiliki oleh green coke sebesar 0,107 g/mnt yang dicapai pada menit ke 12, sedangkan kokas impor memerlukan waktu 129 menit untuk mencapai laju pembakaran tertinggi sebesar $0,057 \mathrm{~g} / \mathrm{mnt}$. Temperatur pembakaran tertinggi yang dicapai kedua kokas hampir sama yaitu $622 P^{o P} C$ untuk green coke dan $633 P^{o P} C$ untuk kokas impor. Untuk masa awal yang sama 5 gram, green coke membutuhkan waktu pembakaran 90 menit sedangkan waktu pembakaran yang diperlukan kokas impor sebanyak 207 menit.
\end{abstract}

Kata kunci : Kokas impor, Green coke, Temperatur pembakaran, Laju pembakaran

\section{PENDAHULUAN}

Salah satu industri yang memanfaatkan bahan bakar batu bara adalah industri pengecoran logam. Contoh penggunaan batubara yang dekat dengan kita adalah di Industri Pengecoran Logam di Kecamatan Ceper Kabupaten Klaten yang digunakan sebagai bahan bakar utama dalam tungku peleburan logam.
Sektor industri logam merupakan salah satu sektor yang cukup besar menyumbangkan pendapatan asli daerah Provinsi Jawa Tengah, yaitu sekitar $7 \%$ dari total PDRB sektor industri manufaktur Jawa Tengah. Hal ini membuat keterkaitan yang cukup tinggi dengan sektor yang lain. Produk dari sentra industri logam sangat beragam mulai dari alat pertanian sampai 
dengan komponen otomotif dan industri berat. Sentra industri logam Jawa Tengah berada di Kabupaten Tegal dan di Kabupaten Klaten tepatnya di Kecamatan Ceper.

Bahan bakar kupola yang digunakan oleh para pengusaha di Ceper adalah kokas impor yang didatangkan dari negeri Cina. Permasalahan timbul akibat kebijakan Pemerintah Cina yang membatasi ekspor kokasnya sehingga harga kokas impor semakin mahal dan menyebabkan biaya produksi menjadi tinggi.

Untuk mengatasi masalah bahan bakar ini beberapa pengusaha pengecoran logam di Ceper telah berusaha membuat briket kokas lokal, namun kualitas briket kokas batubara yang dibuat sangat rendah dibanding briket kokas impor sehingga mempengaruhi pada proses hasil pembakaran.

Penelitian ini dilakukan untuk mengetahui karakteristik pembakaran dan karakteristik mekanik kokas impor sebagai referensi untuk mendapatkan briket alternatif dari bahan lokal. Sebagai pembanding pada penelitian ini juga dilakukan pengujian terhadap kokas lokal (green coke).

\section{TINJAUAN PUSTAKA}

Ragland dan Yang (1995), meneliti pembakaran partikel 4 jenis batubara berdiameter 4-12 mm pada tekanan atmosfer dalam suatu convective thermogravimetry analyzer, temperatur tungku 900 $\mathrm{K}$ s.d. $1200 \mathrm{~K}$ dan kecepatan gas $2 \mathrm{~m} / \mathrm{s}$ s.d. $8 \mathrm{~m} / \mathrm{s}$. Ketika temperatur dinaikkan dari 900 $\mathrm{K}$ menjadi $1200 \mathrm{~K}$ burnout time berkurang setengahnya. Sedangkan pada temperatur $1100 \mathrm{~K}$, ketika kecepatan gas dinaikkan dari $1,7 \mathrm{~m} / \mathrm{s}$ menjadi $3,4 \mathrm{~m} / \mathrm{s}$ waktu pembakaran (burning time) menurun.

Pengaruh tipe batubara, massa partikel, temperatur, laju aliran udara, jumlah partikel dan lapisan abu terhadaap laju pembakaran telah diteliti oleh Blackham et al. (1994), untuk partikel batubara berukuran 5-10 mm. Pada oksidasi partikel arang besar, diameter efektif massa arang berkurang secara linear dengan bertambahnya waktu, kecuali pada akhir dari burnout, massa awal partikel merupakan faktor utama yang mempengaruhi waktu pembakaran. Waktu pembakaran total sebanding dengan kuadrat dari diameter efektif awal partikel. Pada kondisi pembakaran $1270 \mathrm{~K}$ s.d. $1470 \mathrm{~K}$, pengaruh temperatur tidak signifikan terhadap waktu pembakaran partikel dibandingkan dengan pengaruh massa awal partikel. Pembakaran 0,2 gram partikel pada temperatur $670 \mathrm{~K}$ s.d. $1280 \mathrm{~K}$ menunjukkan waktu pembakaran menurun dengan naiknya temperatur dan waktu pembakaran menurun dari 20 menit menjadi 8 menit, dengan naiknya Bilangan Reynold dari 2 menjadi 77 pada temperatur oksidasi $1070 \mathrm{~K}$.

Beteman et al. (1995), meneliti pengurangan massa dan waktu pembakaran dari partikel batubara seberat 0,1 gram dan 0,2 gram dengan diameter $5,5 \mathrm{~mm}$ dan $8 \mathrm{~mm}$ pada tekanan $101 \mathrm{kPa}$. s.d. $760 \mathrm{kPa}$ dalam sebuah reaktor tekanan tinggi (high pressure controlled profile, HPCP reactor). Temperatur udara reaktor pada saat penelitian $900 \mathrm{~K}$ dan $1200 \mathrm{~K}$, Bilangan Reynold aliran udara 63 dan 123. Pembakaran 0,2 gram partikel memerlukan waktu oksidasi total rata-rata 275 detik, sedangkan untuk pembakaran 0,1 gram memerlukan waktu rata-rata 184 detik. Ini menunjukkan hubungan yang linier antara waktu pembakaran dengan diameter awal partikel. Penelitian pengaruh temperatur gas pada $900 \mathrm{~K}$ s.d. $1200 \mathrm{~K}$ terhadap waktu oksidasi, menunjukkan bahwa waktu oksidasi rata-rata untuk partikel kecil berkurang dari 199 detik menjadi 124 detik, sedangkan untuk partikel besar berkurang dari 308 detik menjadi 182 detik untuk semua kondisi percobaan. Laju aliran pada 
bilangan Reynold 63 dan 126 tidak banyak berpengaruh terhadap waktu pembakaran. Pada percobaan ini, laju aliran udara mengurangi waktu pembakaran pada bilangan Reynold $\leq 20$, tetapi tidak banyak berpengaruh pada bilangan Reynold yang lebih besar.

Saptoadi (2004), melakukan penelitian mengenai karakteristik pembakaran briket dari serbuk gergajian dan lignit. Dalam penelitiannya dinyatakan bahwa bahan bakar briket dapat dibuat dalam berbagai bentuk. Bentuk yang paling sederhana adalah silinder dan prisma persegi, karena keduanya mudah untuk dibuat. Dinyatakan juga bahwa bahan bakar briket dengan kandungan biomassa lebih akan memiliki periode pembakaran yang lebih singkat, disebabkan kandungan volatile matter yang tinggi akan dengan mudah dan cepat keluar selama tahap awal proses pembakaran. Bahan bakar briket dengan kandungan batubara lebih banyak dapat mencapai laju pembakaran yang lebih rendah tetapi menghasilkan temperatur gas pembakaran lebih tinggi, disebabkan karena tingginya nilai kalor. Selain itu, dinyatakan juga bahwa bentuk silinder dan prisma persegi hampir menunjukkan waktu pembakaran yang sama.

Kuncoro dkk. (1999), meneliti pembakaran briket tanpa karbonasi akan menyebabkan penyalaan briket menjadi mudah dibandingkan dengan briket yang telah dikarbonasi. Hal ini dikarenakan briket

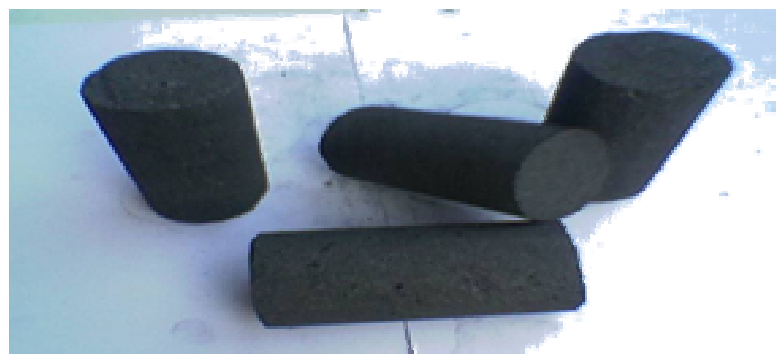

Gambar 1. kokas impor untuk uji mekanis tanpa karbonasi masih mengandung kadar volattile matter yang cukup banyak. Disamping itu mekanisme perubahan panas briket juga akan berubah. Sementara itu Zapusek et al. (2003), melakukan penelitian mengenai pengaruh temperatur dan lama pembakaran terhadap sifat-sifat dasar batubara setelah dikarbonasi. Hasil penelitiannya menyebutkan bahwa untuk variasi temperatur karbonasi semakin tinggi akan meningkatkan kandungan karbon, nilai kalori, abu dan sulfur sedangkan kandungan air, zat volatile matter dan hidrogen akan menurun. Untuk variasi waktu karbonasi yang dilakukan pada temperatur karbonasi yang sama dihasilkan bahwa semakin lama waktu karbonasi maka kandungan kalori, karbon, sulfur dan abu akan meningkat, sedangkan untuk kan-dungan air, zat volatile matter dan hidrogen serta nitrogen menurun.

\section{METODOLOGI PENELITIAN \\ Bahan Penelitian}

1. Kokas impor dari Cina.

2. Kokas lokal (Green coke).

Bongkahan-bongkahan kokas impor dan green coke dibentuk silinder dengan diameter $4 \mathrm{~cm}$, panjang $8 \mathrm{~cm}$ untuk pengujian sifat mekanik, sedangkan untuk pengujian pembakaran dibentuk dengan diameter 2,3 $\mathrm{cm}$ dan massa 5 gram. Bahan penelitian selengkapnya dapat dilihat pada gambar1-4.

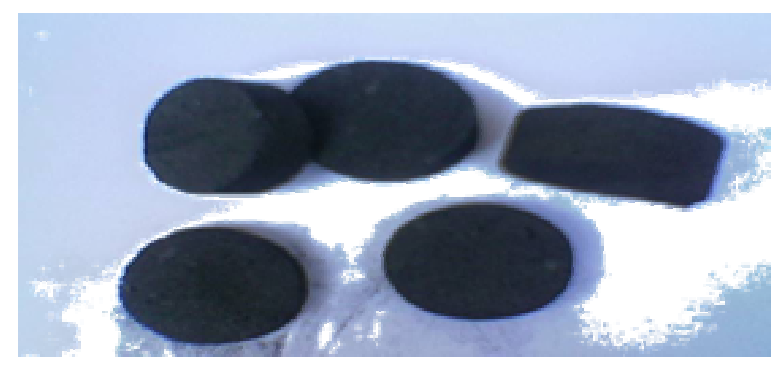

Gambar 2. Kokas impor untuk uji pembakaran 




Gambar 3. green coke untuk uji mekanis

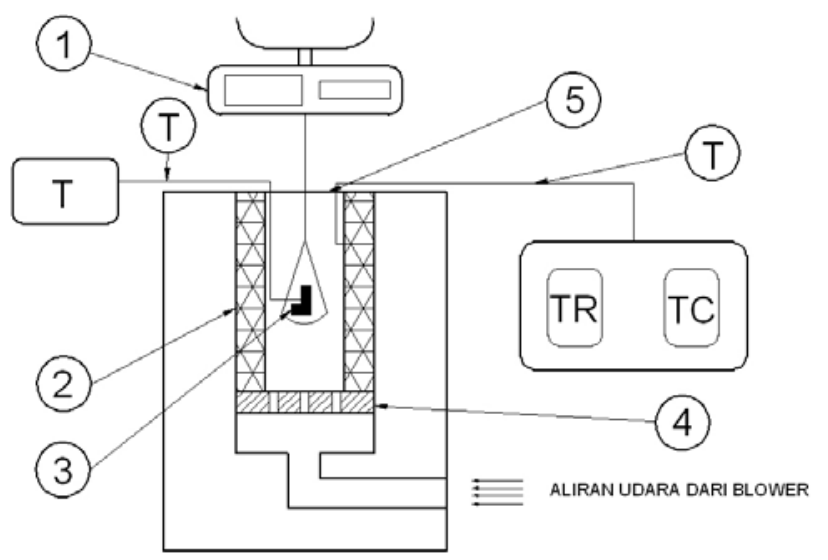

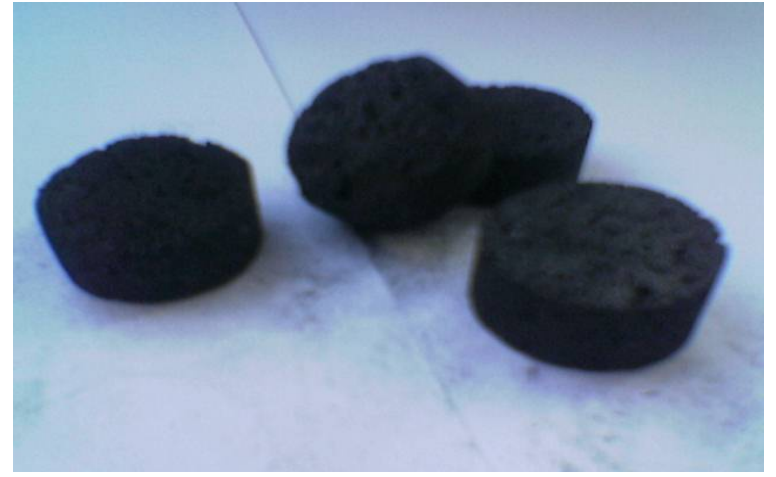

Gambar 4. Green coke untuk uji pembakaran

1. Timbangan Digital

2. Elemen Pemanas Elektrik

3. Briket

4. Saluran Udara

5. Ruang Bakar

T. Thermocouple

TR. Thermocouple Reader

TC. Thermo Controler

\section{Gambar 5. Skema instalasi pengujian}

\section{Alat Penelitian}

Peralatan penelitian meliputi:

1. Timbangan Digital.

2. Gerenda Potong.

3. Amplas.

4. Tungku elektrik.

5. Termokopel reader.

6. Stop watch.

\section{Jalan Penelitian}

1. Analisis proximate dan analisis ultimate dilakukan di Laboratorium Energi Kayu Fakultas Kehutanan dan Pusat Studi Pangan dan Gizi Universitas Gadjah Mada. Analisis proximate, untuk mengetahui kadar air, volatile matter, fixed carbon, dan kadar kalori. Analisis ultimate untuk membandingkan dan menghubungkan sifat-sifat dari kokas disamping untuk memperkirakan nilai kalor dan menentukan kadar karbon, hidrogen $\left(\mathrm{H}_{2}\right)$, dan abu.

2. Pengujian sfat mekanis untuk mengetahui kuat tekan dan kuat kejut dari kokas impor dan green coke. Pengujian ini menggunakan alat Universal Testing Machine (UTM) di Laboratorium Tanah Teknik Sipil Fakultas Teknik UNS.

3. Pengujian karakteristik pembakaran dilaksanakan di Laboratorium Teknik Mesin UMS dengan prosedur sebagai berikut :

a. Hidupkan tungku dan setting temperatur yang dikehendaki. 
b. Masukkan benda uji ke dalam cawan pada ruang bakar, catat massa benda uji.

c. Pasang termokopel di atas benda uji, catat temperatur awal.

d. Catat perubahan massa dan temperatur benda uji setiap satu menit.

\section{HASIL DAN PEMBAHASAN}

Sifat-sifat dasar kokas impor dan green coke yang diperoleh dari analisis proximate dan ultimate ditampilkan pada Tabel 1. sebagai berikut. Adapun hasil pengujian kuat tekan benda uji berbentuk silinder dengan diameter $40 \mathrm{~mm}$ dan panjang 80 mm diberikan pada Tabel 2 .

Sementara itu pengujian kuat kejut dilakukan dengan cara menumbukkan beban seberat $2 \mathrm{~kg}$ ke masing-masing benda uji. Pengujian dihentikan setelah benda uji hancur.

Tabel 1. Sifat dasar kokas impor dan green coke

\begin{tabular}{|l|r|r|}
\hline \multirow{2}{*}{\multicolumn{1}{|c|}{ Kandungan }} & \multicolumn{2}{c|}{ Jenis Kokas } \\
\cline { 2 - 3 } & \multicolumn{1}{c|}{ Kokas Impor } & \multicolumn{1}{c|}{ Green Coke } \\
\hline Kadar air & $0,671 \%$ & $4,420 \%$ \\
\hline Volatile matter & $9,332 \%$ & $4,585 \%$ \\
\hline Kadar Abu & $31,122 \%$ & $1,883 \%$ \\
\hline Fixed carbon & $58,875 \%$ & $89,122 \%$ \\
\hline Nilai kalor & $6970,707 \mathrm{kal} / \mathrm{g}$ & $7803,852 \mathrm{kal} / \mathrm{g}$ \\
\hline
\end{tabular}

'abel 2. Hasil pengujian kuat tekan kokas impor dan green coke.

\begin{tabular}{|l|c|c|}
\hline Jenis Kokas & $\begin{array}{c}\text { Massa Kokas } \\
(\mathrm{g})\end{array}$ & $\begin{array}{c}\text { Kuat Tekan } \\
\left(\mathrm{kg} / \mathrm{cm}^{2}\right)\end{array}$ \\
\hline Kokas impor & 196 & 168.939 \\
\hline Green coke & 149 & 43.182 \\
\hline
\end{tabular}

Hasil pengujian sifat mekanis yang dilakukan menunjukkan bahwa kokas impor lebih unggul dibanding green coke. Kuat tekan green coke hanya 25,56\% dibanding kuat tekan kokas impor, sedangkan kuat kejut green coke hanya $27,59 \%$ dibanding kuat tekan kokas impor. Perbedaan sifat mekanis ini dimungkinkan adanya perbedaan kondisi fisik kokas. Berdasarkan pengamatan foto mikro terlihat bahwa green coke memiliki pori-pori yang lebih besar dibanding kokas impor.
Tabel 3. Hasil pengujian kuat kejut kokas impor dan green coke.

\begin{tabular}{|l|c|c|}
\hline \multicolumn{1}{|c|}{ Jenis Kokas } & Beban $(g)$ & $\begin{array}{c}\text { Banyak } \\
\text { tumbukan }\end{array}$ \\
\hline Kokas impor & 2000 & 2.667 kali \\
\hline Green coke & 2000 & 9.667 kali \\
\hline
\end{tabular}

Adapun sifat-sifat dasar kokas yang berpengaruh terhadap kualitas pembakaran, diketahui bahwa green coke memiliki beberapa keunggulan dibanding kokas impor. Sifat-sifat dasar green cooke untuk fixed carbon, kadar abu, dan nilai kalor lebih baik dibanding kokas impor. Keunggulan sifat-sifat dasar kokas impor yang dimiliki adalah kandungan air yang rendah dan tingginya kandungan volatile matter yang membuat kokas impor lebih mudah dibakar. 
Karakteristik laju pembakaran terhadap dapat dilihat pada gambar berikut. waktu antara kokas impor dan green coke

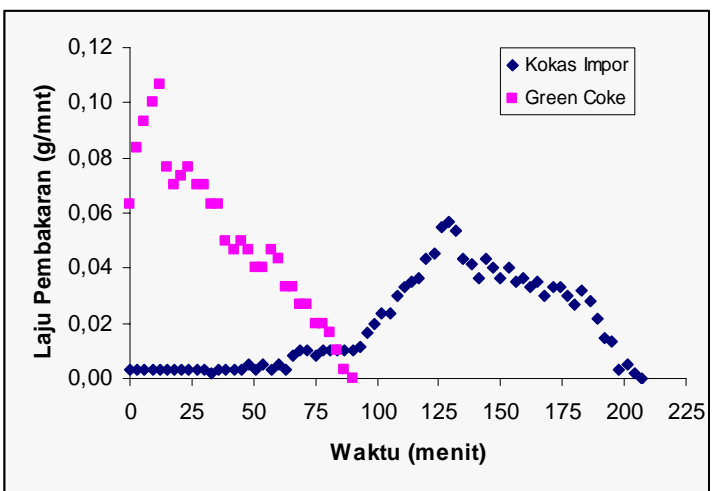

Gambar 6. Grafik Laju pembakaran kokas impor dan green coke.

Gambar 6. memperlihatkan bahwa laju pembakaran green coke naik dari menit ke 0 sampai menit ke 12 dengan laju pembakaran terbesar $0,107 \mathrm{~g} / \mathrm{mnt}$ terjadi pada menit ke 12. Hal ini berbeda jika dibandingkan dengan kokas impor yang memerlukan waktu 129 menit untuk mencapai laju pembakaran tertinggi sebesar $0,057 \mathrm{~g} / \mathrm{mnt}$. Pada tahap ini proses pembakaran berlangsung dengan membaranya kokas hingga berwarna merah, hal ini diperkirakan proses terbakarnya volatile matter.. Green coke lebih cepat terbakar dibandingkan kokas impor, untuk massa

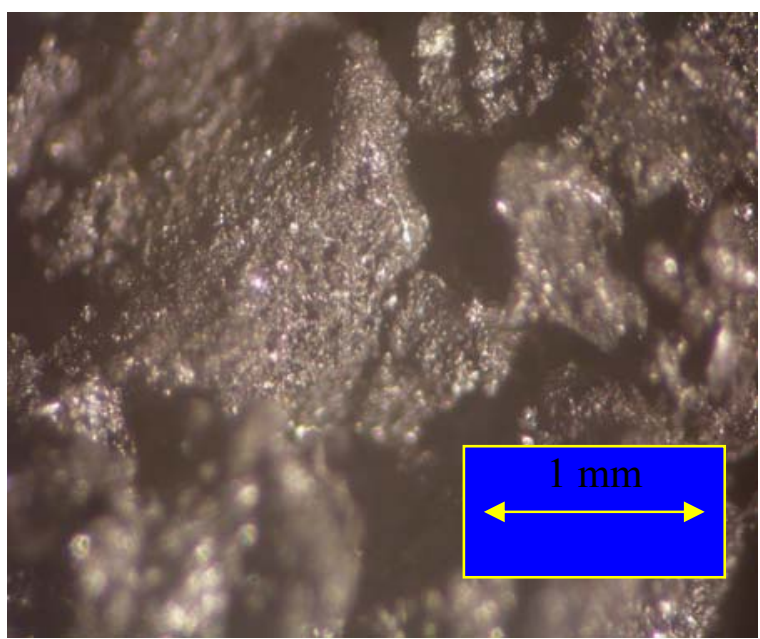

Gambar 7. Foto mikro green coke skala 4x awal yang sama 5 gram green coke membutuhkan waktu pembakaran 90 menit sedangkan waktu pembakaran yang diperlukan kokas impor sebanyak 207 menit.

Perbedaan karakteristik laju pembakaran antara kokas impor dengan green coke yang sangat signifikan tidak sesuai dengan sifat-sifat dasarnya pada Tabel 1 . Hal lain yang dapat dikemukakan untuk menjelaskan perbedaan karakteristik laju pembakaran adalah perbedaan pori-pori antara kokas impor dengan green coke.

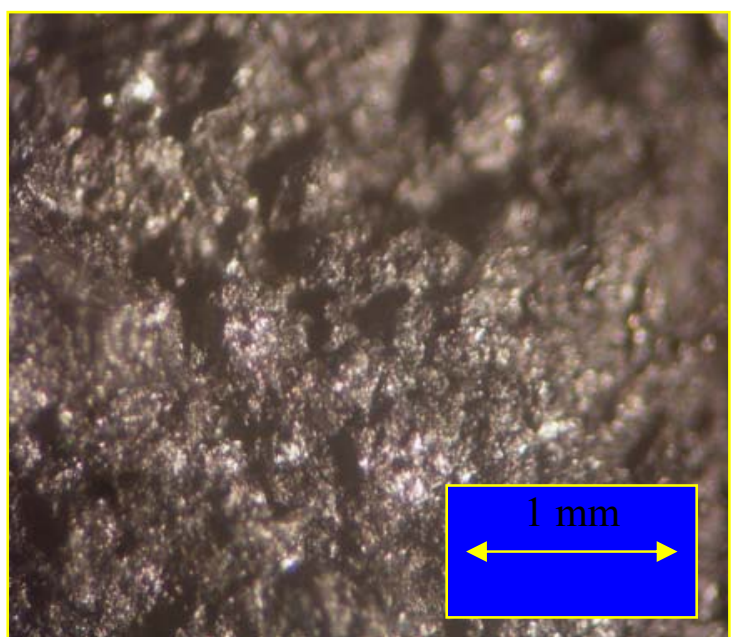

Gambar 8. Foto mikro kokas impor skala 4x 


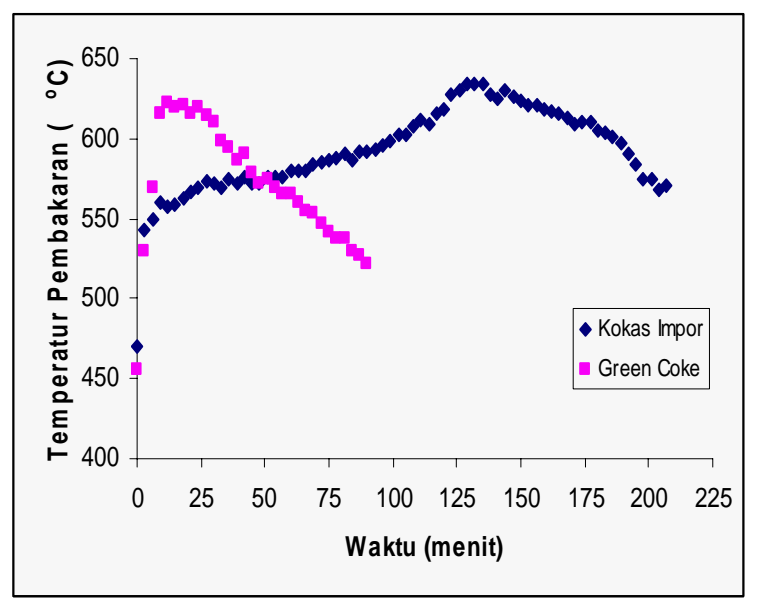

Gambar 10. Grafik penurunan massa kokas impor dan green coke

Gambar 7 dan 8 memperlihatkan bahwa pori-pori green coke berukuran besar dan relatif menggumpul, sedangkan pori-pori pada kokas impor terlihat berukuran kecilkecil dan menyebar. Kondisi ini mempengaruhi kekuatan mekanik dan karakteristik pembakarannya. Struktur poripori yang besar menyebabkan lemahnya kemampuan mekanik dan mempermudah masuknya $\mathrm{OB}_{2 \mathrm{~B}}$ dalam pori-pori kokas selama pembakaran. Sedangkan struktur pori-pori yang kecil dan tersebar akan menyebabkan ketahan mekanik yang baik dan distribusi $\mathrm{OB}_{2 \mathrm{~B}}$ yang lebih banyak di permukaan.

Karakteristik temperatur pembakaran hasil ditunjukkan pada Gambar 9. Pada awal pembakaran, temperatur pembakaran green coke naik hingga mencapai temperatur tertinggi sebesar $622 \mathrm{P}^{0 \mathrm{P}} \mathrm{C}$ pada menit ke 12. Temperatur pembakaran cenderung konstan dengan kisaran di atas $600 \mathrm{P}^{\mathrm{oP}} \mathrm{C}$ sampai menit ke 30 , selanjutnya turun secara perlahan mencapai temperatur $522 \mathrm{P}^{\mathrm{oP}} \mathrm{C}$ pada akhir pembakaran green coke yaitu pada menit ke 90. Pada akhir pembakaran ini green cooke meninggalkan massa sisa sebesar 0,30 gram.

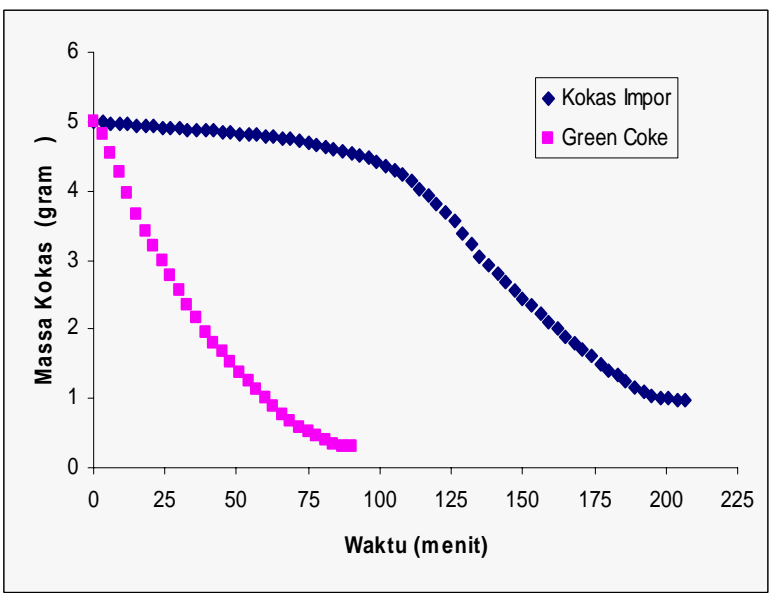

Gambar 9. Grafik temperatur pembakaran kokas impor dan green coke.

Kondisi ini memperlihatkan bahwa besarnya temperatur pembakaran mempengaruhi laju pembakaran. Temperatur pembakaran tertinggi green coke adalah $622 \mathrm{P}^{\mathrm{oP}} \mathrm{C}$ yang dicapai pada menit ke 12, pada saat yang bersamaan laju pembakaran juga memiliki nilai terbesar yaitu $0,107 \mathrm{~g} / \mathrm{mnt}$.

Pada grafik hubungan antara temperatur pembakaran terhadap waktu pembakaran memperlihatkan bahwa awal pembakaran kokas impor memerlukan temperatur yang tinggi dan waktu yang lama untuk terbakar. Kokas impor mencapai temperatur tertinggi yaitu $633 \mathrm{P}^{\mathrm{oP}} \mathrm{C}$ pada menit ke 130 . Seperti halnya green coke laju pembakaran tertinggi kokas impor juga terjadi pada temperatur puncaknya yaitu $0,057 \mathrm{~g} / \mathrm{mnt}$ pada menit ke 129. Lamanya kokas impor terbakar tidak terlepas dari partikel pembentuknya yang berongga dan berpori-pori kecil. Semakin kecil pori-pori akan menyebabkan distribusi $\mathrm{OB}_{2 \mathrm{~B}}$ lebih banyak terdapat permukaan kokas tidak mudah masuk ke dalam pori-pori. Hal ini membuat proses pembakaran kokas impor hanya terjadi di permukaan luar. Temperatur pembakaran cenderung konstan dengan kisaran diatas 600 sampai menit ke 177 dan perlahan- 
lahan menurun mencapai temperatur terendah yaitu $568 \mathrm{P}^{\mathrm{oP}} \mathrm{C}$ pada menit ke 204.

Penurunan massa kedua kokas dapat dilihat pada gambar 10 .

\section{KESIMPULAN}

Berdasarkan data hasil penelitian dan analisis data yang diperoleh selama penelitian yang dilakukan, dapat disimpulkan sebagai berikut.

1. Kokas impor mempunyai kuat tekan 3,9 kali kuat tekan green coke yaitu $168,939 \mathrm{~kg} / \mathrm{cm}^{2}$ dibanding 43,182 $\mathrm{kg} / \mathrm{cm}^{2}$, sedangkan kuat kejut kokas impor 3,6 kali green coke.

2. Laju pembakaran tertinggi terjadi pada temperatur puncak pembakaran kedua kokas. Laju pembakaran terbesar dimiliki oleh green coke sebesar 0,107 $\mathrm{g} / \mathrm{mnt}$ yang dicapai pada menit ke 12 , sedangkan kokas impor memerlukan waktu 129 menit untuk mencapai laju pembakaran tertinggi sebesar 0,057 $\mathrm{g} / \mathrm{mnt}$. Temperatur pembakaran tertinggi yang dicapai kedua kokas hampir sama yaitu $622{ }^{\circ} \mathrm{C}$ untuk green coke dan $633{ }^{\circ} \mathrm{C}$ untuk kokas impor. Untuk masa awal yang sama 5 gram, green coke membutuhkan waktu pembakaran 90 menit sedangkan waktu pembakaran yang diperlukan kokas impor sebanyak 207 menit.

\section{DAFTAR PUSTAKA}

Beteman, K. J., Germane. G. J., Smoot. L. D., Blackham, A. U. and Eatough. C. N., 1994, Effect or Pressure on Oxidation Rate Of Millimetre-Sized Char Particles, Brigham Young University, Provo, UT 84602, USA.

Blackham, A. U., Smoot, L. D. and Yousefi. P., 1992, Rates of Oxidation of millimeter-Sized Char Particles: Simple Experiment, Brigham Young University, Provo, UT 84602, USA.

Kuncoro, H., Herbawamurti, T.E, Hawaria, Darmawan, 1999, Study On Coal Briquettes Stove In Indonesia, Energy Technology Laboratory, LSDE-BPPT, Jakarta.

Ragland, K.W, Yang, J.T, 1995, Combustion of millimeter sized coal particles in convective flow, Combustion and Flame.

Saptoadi, H., 2004, Combustion Characteriastics Of Fuel Briquettes Made From Wooden Saw Dust And Lignite. The International Workshop On Biomass And Clean Fossil Fuel Power Plan Technology 2004. Jakarta Indonesia. pp186-199.

Zapusek, A., Wirtgen, C., Lenart, F., 2003, Characterisation Of Carbonizate Produced From Velenje Lignite In Lab-Scale Reactor, ERICo Velenje, Institute for Ecological reseach, Koroska 58, 3320 Velenje, Slovania. 